Published in final edited form as:

Exp Eye Res. 2015 March ; 0: 198-207. doi:10.1016/j.exer.2015.01.014.

\title{
Corneal Stroma Microfibrils
}

\author{
Samuel D. Hanlon a, ${ }^{*}$, Ali R. Behzad ${ }^{b}$, Lynn Y. Sakaic ${ }^{c}$, and Alan R. Burns ${ }^{a, d}$ \\ ${ }^{a}$ College of Optometry, University of Houston, Houston, TX, 97204 USA \\ bImaging and Characterization Core Lab, King Abdullah University of Science and Technology, \\ Thuwal, Kingdom of Saudi Arabia \\ 'Shiners Hospital for Children and Department of Biochemistry and Molecular Biology, Oregon \\ Health \& Science University, Portland Oregon, 97239 USA \\ dDepartment of Pediatrics, Baylor College of Medicine, Houston, TX, 77030 USA
}

\section{Abstract}

Elastic tissue was first described well over a hundred years ago and has since been identified in nearly every part of the body. In this review, we examine elastic tissue in the corneal stroma with some mention of other ocular structures which have been more thoroughly described in the past. True elastic fibers consist of an elastin core surrounded by fibrillin microfibrils. However, the presence of elastin fibers is not a requirement and some elastic tissue is comprised of non-elastincontaining bundles of microfibrils. Fibers containing a higher relative amount of elastin are associated with greater elasticity and those without elastin, with structural support. Recently it has been shown that the microfibrils, not only serve mechanical roles, but are also involved in cell signaling through force transduction and the release of TGF- $\beta$. A well characterized example of elastin-free microfibril bundles (EFMBs) is found in the ciliary zonules which suspend the crystalline lens in the eye. Through contraction of the ciliary muscle they exert enough force to reshape the lens and thereby change its focal point. It is believed that the molecules comprising these fibers do not turn-over and yet retain their tensile strength for the life of the animal. The mechanical properties of the cornea (strength, elasticity, resiliency) would suggest that EFMBs are present there as well. However, many authors have reported that, although present during embryonic and early postnatal development, EFMBs are generally not present in adults. Serialblock-face imaging with a scanning electron microscope enabled 3D reconstruction of elements in murine corneas. Among these elements were found fibers that formed an extensive network throughout the cornea. In single sections these fibers appeared as electron dense patches. Transmission electron microscopy provided additional detail of these patches and showed them to be composed of fibrils ( $\sim 10 \mathrm{~nm}$ diameter). Immunogold evidence clearly identified these fibrils as fibrillin EFMBs and EFMBs were also observed with TEM (without immunogold) in adult

\footnotetext{
(C) 2015 Published by Elsevier Ltd.

"Corresponding author: College of Optometry, University of Houston, 505 J. Davis Armistead, Houston, Texas. Tel.: 713.743.2576; fax: 713.743.2053, shanlon@ optometry.uh.edu (S.D. Hanlon).

Publisher's Disclaimer: This is a PDF file of an unedited manuscript that has been accepted for publication. As a service to our customers we are providing this early version of the manuscript. The manuscript will undergo copyediting, typesetting, and review of the resulting proof before it is published in its final citable form. Please note that during the production process errors may be discovered which could affect the content, and all legal disclaimers that apply to the journal pertain.
} 
mammals of several species. Evidence of the presence of EFMBs in adult corneas will hopefully pique an interest in further studies that will ultimately improve our understanding of the cornea's biomechanical properties and its capacity to repair.

\section{Keywords}

microfibrils; fibrillin; cornea; oxytalan; elastic tissue

\section{Introduction}

The cornea is a complex and precisely structured tissue, resilient and uniquely transparent, endowed with optical properties making vision possible, yet deceivingly simplistic in its macroscopic appearance. It is composed of three cellular regions: stratified squamous anterior epithelium, stroma, and posterior endothelium. In humans, $90 \%$ of the corneal thickness is attributed to the stroma which is classified as regular, fibrocollagenous, dense connective tissue. Corneal transparency requires the stromal collagen fibrils, which are organized into tightly-spaced bands (lamellae) of parallel fibrils laid down in criss-crossed fashion, be uniformly sized and spaced (Goldman et al., 1968; Maurice, 1957). In addition to the major component, type I collagen, there are several other minor collagens and ground substance consisting of glycosaminoglycans, proteoglycans, and glycoproteins (Hassell and Birk, 2010).

As the main refractive component of the eye, the cornea must not only be transparent but must also maintain a precisely-shaped, regular surface while providing strength and resiliency to withstand significant mechanical forces from external sources and intraocular pressure variation (Coleman and Trokel, 1969; Hann and Fautsch, 2011). These biomechanical stresses require tissue deformation and recoil; a characteristic common to elastic tissue, yet definitive evidence of the presence of elastic tissue microfibrils in the corneal stroma is limited.

The purpose of this paper is to review what is known about elastic tissue microfibrils specifically in regards to the corneal stroma in hopes of stimulating new research efforts aimed at elucidating their role in the cornea. Corneal disease and trauma negatively impact vision, so there is a continuing need to better understand how the cornea responds to injury. A better understanding of corneal microfibrils is likely to lead to an improved understanding of corneal biomechanics, homeostasis and the cornea's response to insult.

\section{Historical review of elastic tissue}

A brief review of elastic tissue is important for understanding the possible role of elastic tissue microfibrils within the corneal stroma. The biomechanical properties of the cornea imply the presence of elastic tissue but what has been learned from microfibrils in structures other than the cornea reveals additional functions beyond mechanical. The corollary functions of microfibrils in the cornea are largely unknown.

A number of books and articles were published during the mid-19 $19^{\text {th }}$ century apparently as a result of a keen interest in understanding the characteristic of elastic tissue, which had only 
recently been described by Donders in 1846 (Kolliker, 1860; Lehmann, 1855). While many of the observations were quite accurate, conclusions drawn from these early studies have since been modified or out-right rejected in light of new evidence. For example, one early author described a delicate system of nutrient channels in connective tissue that transforms into elastic tissue when required (Virchow, 1863). A century later Fullmer \& Lillie (1958) (Fullmer and Lillie, 1958) used selective staining methods to reveal connective tissue fibers that could be distinguished from collagen, elastic, and reticular fibers (type III collagen secreted by reticular cells as a supporting mesh in soft tissues). These fibers were found to be resistant to acid hydrolysis and were named "oxytalan" (meaning acid resistant) fibers.

In the 1960's, the field of biological electron microscopy was developing rapidly and it was during this time that Low (1962) described the fine structure of microfibrillar elements of the extracellular matrix (Low, 1962). He reported microfibril ultrastructure as being variable in diameter $(4-12 \mathrm{~nm})$ with frequent branching. It was later shown that individual microfibrils are unbranching but form bundles which do branch, (Kielty and Shuttleworth, 1995; Sakai et al., 1986). According to Low's observations the fibrils seemed to be in all connective tissue but were most noticeable in formed elastic fibers and basement membranes with some microfibrils appearing to have a dense outer shell and lucid core. A few years later Haust, et al. (1965) (Haust, 1965; Haust et al., 1965) made similar observations and reported that elastic fibers had a homogenous core with a surrounding "elastic membrane" and fibrils around the outside. The elastic fibers were reported to be $50-150 \mathrm{~nm}$ in diameter and the microfibrils within the fibers had a diameter of $10 \mathrm{~nm}$ and a periodicity of $15 \mathrm{~nm}$ (microfibril periodicity was later shown to be consistently $50-56 \mathrm{~nm}$ when tension-free). They proposed connective tissue microfibrils and collagen fibrils share a common precursor (tropocollagen) and the microfibril of the extracellular matrix is a common denominator in collagenous and elastic tissues. They also subscribed to an earlier notion that degraded collagen fibers combine with mucopolysaccharide (glycosaminoglycan) to form microfibrils. The microfibrils they observed were 4-14nm in diameter and therefore similar to those described by Low.

At that time (ca. 1965) the chemical composition of elastic fibers was not known but they could be identified by various stains such as aldehyde fuchsin and orcein. In 1966 Greenlee et al. (Greenlee et al., 1966) used an electron microscope to examine the fine structure of immature elastic fibers and concluded they were the precursor to mature elastic fibers. In 1969 Ross \& Bornstein (Ross and Bornstein, 1969), proposed that microfibrils and the amorphous component of elastic fibers are two different proteins, or different forms of elastin (the amorphous substance being altered microfibrils). Using electron microscopy and selective degradation they showed the microfibrils to be a second but unknown protein and also described microfibrils as being in close apposition to cells, often found in cell infoldings.

Fibers in the elastic system were grouped into 3 categories depending on the relative amount of elastin as compared to microfibrils (Gawlik, 1965). True "elastic" fibers are predominantly elastin with a coating layer of microfibrils on the outside of the fiber, "elaunan" fibers have proportionately more microfibrils, with some interspersed within the fiber core. "Oxytalan" fibers are composed of only microfibrils. Differential staining 
(aldehyde fuchsin, with and without oxidation, for example) identifies the different fibers (Alexander et al., 1981; Carrington et al., 1984; Fullmer and Lillie, 1958). The 3 types of fibers were confirmed with electron microscopy as having distinct ultrastructural morphologies (Cotta-Pereira et al., 1976). It has been proposed that microfibrils present a scaffold for elastin deposition during elastogenesis and many authors agree that the 3 fiber types are a continuum of maturity, where oxytalan represents immature elastic fibers. However, some authors raised the possibility that microfibrils of elastin-free fibers might be a somewhat different variant. Elastic tissue then includes fibers that are predominantly elastin, those that are exclusively microfibrils, and a continuum intermediate phase of varying proportional composition.

The term "microfibril" has been adopted by many authors to refer specifically to extracellular fibrillin-containing microfibrils. Hence, in this review we will simply use the term "microfibril" to refer to extracellular fibrillin-containing microfibrils and bundles of elastin-free microfibrils will be referred to as (EFMBs).

Elastic tissue is formed during early development with minimal if any turn over in mature tissues (Davis, 1993). Once damaged, elastic tissue may reactivate elastogenic cells but this typically results in abnormal tissue which may even impair normal function (Kuhn et al., 1976). Surprisingly this observation was also reported by Kolliker in 1858 (Kolliker, 1860). Little is known about the half-life of microfibrils but they apparently exist for exceedingly long periods of time possibly up to the life of the animal and it has been reported they are non-self-renewing (Garner and Alexander, 1986; Kielty and Shuttleworth, 1995; Sherratt, 2009; Yanagisawa and Davis, 2010). Degeneration of existing microfibrils results in loss of elasticity (increase in rigidity) with advancing age (senile elastosis) as seen for example in skin (Banfield and Brindley, 1963; Sherratt, 2009).

Elastic tissue is an integral/major component in most tissues and has been extensively studied in many tissues such as skin, aorta, and tendon. In tissues that are more elastic in nature, there are more elastic fibers; where strength and support are needed, there are more elastin-free fibers. These latter fibers have been extensively studied using the periodontal and nuchal ligaments.

Elastic tissue has been described in many ocular structures and generally consists of a range of fiber maturity from elastin-free microfibril bundles to mature elastic fibers with an elastin core and microfibril mantle. The human sclera is a good example of the continuum of elastic fiber maturity and like skin it shows signs of senile elastosis with advancing age (Kanai and Kaufman, 1972). Lens zonules have been one of the more thoroughly studied ocular structures and shown to consist of pure microfibrils (elastin-free) that never develop into elastic fibers, thereby providing a relatively stable support for the lens (Streeten et al., 1981). Elastic tissue is also a significant component of justacanulicular tissue and Schlemm's canal, as well as the lamina cribrosa in the optic nerve head. It is therefore highly likely that degeneration or alteration of elastic tissue fibers would impact outflow resistance and dysregulate intraocular pressure, while rendering the lamina cribrosa more vulnerable to pressure-induced optic nerve damage. Both of which would contribute to the development of 
glaucoma (Hann and Fautsch, 2011; Kuchtey and Kuchtey, 2014; Zenkel and SchlotzerSchrehardt, 2014).

\section{Evidence of elastic tissue in cornea stroma}

In 1903 professor Ferruccio Tartuferi of the University of Bologna, Italy published a seminal report which described an extensive network of "elastic fibers" in the corneal stroma (Abelsdorff, 1904; Tartuferi, 1903). Apparently this was not a novel finding since half a century earlier Kolliker (Kolliker, 1860) stated the elastic tissue in the cornea remains in an embryonic stage (presumably elastin free). In spite of these early observations and, even though fibrillin microfibrils have been said to be ubiquitous, evidence that EFMBs exist in the adult normal corneal stroma (not immature or diseased) is non-definitive.

The early 1980's to late 1990's seemed to be a time of piqued interest in corneal microfibrils. In 1987 Bruns et al. examined the corneal stroma of a variety of species and found they all contained some variation of EFMBs. They found them in embryonic chicks and adult chickens though more plentiful in embryos (Bruns et al., 1987). In another study using very young chicks and immunohistochemistry, EFMBs were found throughout the stroma, mostly within lamellae. Their density increased from anterior to posterior and center to periphery with abundant fibers in close proximity to Descemet's membrane (Daga Gordini et al., 1990). In 1988, the corneas of $2 \mathrm{Kg}$ rabbits (adults can weigh as much as $5-8 \mathrm{Kg}$ ) were found to have electron dense patches which at higher magnification appeared as arrays of microfibrils adjacent to keratocytes, found thoughout the full thickness of the stroma and within as well as between lamellae (Carlson and Waring, 1988). Similar fibers were shown to be numerous in newborn kittens and to decrease with age, with the majority of fibers appearing within collagen lamellae rather than between. A few fibers were found in the adult cat but only in the peripheral corneal stroma (Carrington et al., 1984).

In humans, EFMBs have been reported in juveniles and various adult disease states (Akhtar et al., 2001; Garner and Alexander, 1986; Quondamatteo et al., 2002). A weak immunoreactivity for fibrillin was described in patchy bundles between stromal lamellae in adult human corneas (Schlotzer-Schrehardt et al., 1997). However, most authors agree evidence of EFMBs in the normal adult cornea is lacking (Bruns et al., 1987; Carlson and Waring, 1988; Carrington et al., 1984; Garner and Alexander, 1986). EFMBs have been identified in young human eyes using histochemical means and these fibers are said to be located between lamellae and typically parallel with the corneal surface. There have been reports showing evidence of vertical fibers within Descemet's membrane (Alexander and Garner, 1983; Carrington et al., 1984). In older eyes the fibers were only found surrounding Hassall-Henle warts (Alexander and Garner, 1983) or as occasional patches of fibrillin between lamellae (Schlotzer-Schrehardt et al., 1997; Wheatley et al., 1995).

A common finding with TEM imaging of the corneal stroma is what appear to be random electron-dense patches within and between lamellae. Even though published electron micrographs often show these patches, they are generally not mentioned. An example can be seen in figure 1D from a 2001 article. (Birk, 2001).

Exp Eye Res. Author manuscript; available in PMC 2016 March 01. 
A frequently referenced textbook of ocular anatomy includes a figure (figure 3-24 B) with a clear example of an EFMB in cross-section. The figure legend refers to it as a "granular mass", with no further mention (Hogan et al., 1971). In our experience, we have observed these patches in adult animals in a variety of species (Figure 1) and closer examination, showed these patches to be comprised of small $10 \mathrm{~nm}$ diameter tubules with an electron translucent core when viewed in a favorable cross-section. The bundles are approximately $100-200 \mathrm{~nm}$ in diameter, consistent with elastin-free fibrillin microfibrils, and clearly different than other fibrillar components of the stroma, such as collagen VI microfibrils (Fitch et al., 1991) which are much smaller in diameter (3-5 nm). However, as previously mentioned, it is largely accepted that fibrillin microfibrils do not exist in the adult/mature animal/human or they are not reported.

En face projected immunofluorescence imaging using anti-fibrillin antibody (Figure 2) reveals an extensive network of stromal fibers in an adult mouse cornea. These fibers are present throughout the stroma, extending in all directions for considerable distances, though predominantly forming layers parallel with the corneal surface. TEM imaging after silver enhancement of the nanogold particles (Figure 3) reveals silver deposits specifically associated with microfibrillar electron dense patches, confirming the presence of fibrillin- 1 .

Much of the information about the spatial organization of stromal extracellular matrix (ECM) has been obtained by light microscopy (LM), routine transmission electron microscopy (TEM) (Alroy et al., 1999), electron tomography (Parfitt et al., 2010), scanning electron microscopy (SEM), atomic force microscopy (AFM) (Yamamoto et al., 2000), and x-ray scattering (Hayes et al., 2007). Understanding the supramolecular organization of the ECM is somewhat limited when using a method that provides essentially 2D ultrastructural information (TEM), and surface views with limited depth (electron tomography and AFM) and restricted viewing angles (SEM). Serial block-face sectioning SEM overcomes these limitations and provides a unique 3D approach for evaluating ECM ultrastructural organization.

In 2004 Denk and Horstmann (Denk and Horstmann, 2004) demonstrated that an ultramicrotome placed within the vacuum of a scanning electron microscope (SEM) could be used to cut the surface of a plastic embedded tissue block and could then be imaged using backscatter electron detection. This method produced serial sections of tissue blocks that resembled TEM images with only slightly less resolution. Using this method, tissue volumes can be reconstructed with nanometer precision and viewed from any angle.

We recently began using a Gatan 3View automated serial block-face imaging system (Gatan, Inc., Pleasanton, CA). Blocks of adult C57BL/6 mouse cornea tissue processed using a modified protocol to enhance specimen contrast were serially sectioned using the Gatan 3View system mounted inside an FEI Quanta 250 SEM. In this way 500-700 serial block-face images (each image separated by $100 \mathrm{~nm}$ ) were collected and viewed as a precisely registered Z-stack. The electron dense patches, presumed to be EFMBs were segmented and 3D reconstructed using Amira software. The results, shown in Figure 4, reveal a network of fibers at the ultrastructural level where variations in EFMB diameters are discerned. Panels A-C are from the same location in the limbus. The 3D reconstruction 
in panel D (paracentral cornea), if viewed en face, would produce an image similar to the network observed by immunofluorescence (Figure 2). However, in the view shown (essentially transverse) distinct layering is revealed. When keratocytes were included in the reconstruction (Figure 4-C), fibers were seen lying within shallow invaginations (infoldings) located on the keratocyte surface. Likewise, EFMBs are frequently seen in close proximity to, or making contact with keratocytes in TEM micrographs. Figure 5 shows four such images and in panel $\mathrm{C}$ we see electron dense focal adhesions between a keratocyte and EFMB. These observations suggest the possibility that EFMBs serve a role in mechanotransduction between keratocytes and the extracellular matrix. The nature of this intimate relationship between EFMBs and the keratocyte surface deserves further study.

Coincidentally, in vivo confocal microscopy revealed an unidentified filamentous network (Figure 6) which is strikingly similar to the network shown by immunofluorescence and serial SEM imaging. Using a scanning laser confocal microscope (e.g., HRT) it is possible to image a network of fine fibers within the corneal stroma in vivo. Even though these fibers ( $\sim 100 \mathrm{~nm}$ diameter) are well below the resolution of the microscope, specular reflectance provides evidence of the fibers as a factor of brightness of the reflected light, similar to the way spider webs are visible from a great distance when the sun strikes them at a precise angle or a small piece of glass is seen at a great distance when the sun strikes it.

Previously published reports regarding EFMBs in the corneal stroma have largely concluded that they disappear as animals/humans mature, except in disease. Our results provide evidence to the contrary and the fibrils identified as EFMBs form an extensive network within the cornea stroma of adult mice. Our TEM images (Figure 1) suggest they are present in adults of other species of mammals as well.

\section{Fibrillin and its characterization}

Many of the mechanical properties of elastic tissue can be attributed to the molecular structure of the major protein component of the microfibrils. The "unknown" protein of the $10 \mathrm{~nm}$ microfibrils described by Ross \& Bornstein (Ross and Bornstein, 1969) was shown by Sakai, et al. (1986), to be a novel 350kDA protein and given the name "fibrillin" (Sakai et al., 1986). These authors specifically mentioned the distinction between the fibrillin microfibrils and the smaller (3-5nm) collagen VI microfilaments described by Fitch et al. (Fitch et al., 1991). Fibrillin was demonstrated in microfibril bundles both with ("elastic" or "elaunan fibers") and without elastin ("oxytalan fibers"). Ultrastructural analysis revealed a periodicity (50-56nm) within microfibrils which was consistent across bundles of individual microfibrils and suggested an ordered aggregation of individual microfibrils.

Since the discovery of fibrillin protein it has been shown that fibrillins are a group of (at least) three proteins, fibrillin-1, 2, and 3 encoded by separate genes (Corson et al., 2004; Davis, 1994; Jensen et al., 2012; Lee et al., 1991; Zhang et al., 1994).They are found in invertebrates as well as vertebrates and the molecular structure is similar across species (Charbonneau et al., 2003; Faury, 2001; Hubmacher et al., 2008; Quondamatteo et al., 2002). The existence of a family of fibrillins (rather than a single one) raises the possibility of tissue-specific or temporally regulated expression (Rosenbloom et al., 1993). Fibrillin 1, 2

Exp Eye Res. Author manuscript; available in PMC 2016 March 01. 
and 3 are expressed during fetal development, but 1 is by far the most abundant in adult tissues (Corson et al., 2004; Quondamatteo et al., 2002). Fibrillin 1 is predominant in forcebearing structures whereas Fibrillin 2 (and likely 3 ) is associated with elastic fiber assembly (Zhang et al., 1994).

Fibrillin is likely processed extracellularly and polymerization occurs at or near the cell membrane as monomers are secreted (Hubmacher et al., 2008; Kielty and Shuttleworth, 1995; Reinhardt et al., 1996). It is a multdomain molelcule with 47 EGF-like domains, 8cysteine modules, and an RGD putative cell attachment motif (Corson et al., 1993; Maslen et al., 1991; Pereira et al., 1993; Zhang et al., 1994). Single fibrillin monomers are approximately $148 \mathrm{~nm}$ in length and are assembled head-to-tail. Microfibrils may be comprised of homopolymers of each fibrillin type or may form fibrillin- $1 / 2$ heteropolymers (Charbonneau et al., 2003; Charbonneau et al., 2010). The $\mathrm{C}$ terminus of fibrillin-1 apparently multimerizes into a bead-like structure which in turn enhances the avidity of the $\mathrm{N}$-to-C terminus binding (Hubmacher et al., 2008).

There have been at least two broad categories of microfibril organization proposed: a pleated model and an overlapping model (Cain et al., 2006; Jensen et al., 2012; Kuo et al., 2007; Lu et al., 2005; Sherratt et al., 2003). These proposed arrangements attempt to explain how a molecule that is $\sim 148 \mathrm{~nm}$ in length produces fibrils with a beads-on-a-string appearance and a periodicity of $\sim 56 \mathrm{~m}$. The intramolecular folding/overlapping results in approximately $1 / 3$ staggering that is stable at $\sim 56 \mathrm{~nm}$ in relaxed tissue but can be extended to 2-3 fold (Baldock et al., 2001; Keene et al., 1991).

Automated electron tomography has shown that microfibrils consist of approximately 8 fibrillin molecules as seen in cross-section and are constructed of in-register parallel filaments of fibrillin resulting in a microfibril periodicity the same as fibrillin molecular periodicity. This model is consistent with microfibril ultrastructure and provides an explanation for their extensibility. In elastin-free tissues, fibrillin-containing microfibrils confer the properties of elasticity and extensibility to the ECM (Keene et al., 1991;

McConnell et al., 1997) which are critical properties of the cornea. However, even though in all current models monomers are arranged head-to-tail there is still a question of whether elasticity is due to properties of individual microfibrils or the packing arrangement of parallel microfibrils within bundles (or bundle architecture) (Sherratt et al., 2003).

In addition to elasticity, resiliency is also a necessary property for micrifibrils in forcebearing tissues (such as the cornea) and it is the extensive disulphide-bonding that is responsible for resiliency. Calcium binding to the cbEGF (calcium-binding epithelial growth factor) domains produces microfibril rigidity (Eriksen et al., 2001; Jensen et al., 2012). Individual microfibrils act as relatively stiff elastic polymers and perform critical anchoring roles. Microfibrils were shown to be 2 orders of magnitude stiffer than elastin. The elastic fiber (elastin and microfibrils) is likely a microfibril-reinforced fibrous composite. Tissuespecific and organism-specific variations in microfibril bundle organization and elasticity may occur due to subtle variations in ionic environment, inter-microfibrillar cross-links, and/or differences in associated molecules (Sherratt et al., 2003).

Exp Eye Res. Author manuscript; available in PMC 2016 March 01. 
Cells, such as epithelial cells, may deposit fibrillin into a nonfibrillar matrix. Cellular factors or receptors may be required for fibrillin fibril formation and may interact differentially with fibrillin-1 and 2. a $5 \beta 1$ and aV $\beta 3$ integrins are important receptors for fibrillin (Bax et al., 2003; Jensen et al., 2012; Jovanovic et al., 2008) and integrins may be one of these factors required for fibril assembly (Charbonneau et al., 2003; Pfaff et al., 1996). In the cornea the epithelium, keratocytes and endothelium have all been postulated to produce microfibrils. (Carrington et al., 1984; Garner and Alexander, 1986).

\section{Other molecules associated with fibrillin in microfibrils}

Numerous proteins have been identified as components with associations ranging from mere immunolocalization to functional binding interactions as evidenced with knock-out animal models (Hubmacher et al., 2008). Some of these proteins are exclusively associated with microfibrils and may have tissue-specific modulatory effects (microfibril- associatedglycoprotein-1 (MAGP-1) or MAGP-2, for example). Others molecules found in the extracellular matrix (examples fibronectin, fibulin, proteoglycans) may play a role in microfibril interaction with the surrounding extracellular matrix.

MGAP-1 and -2 are probably the best characterized microfibril associated proteins at this time. They are found in association with microfibrils in nearly all (possibly all) tissues, but the distribution of MAGP-2 is more restricted. They are small 31-KD acidic, elastin-binding glycoproteins (Brown-Augsburger et al., 1994; Gibson and Cleary, 1987; Gibson et al., 1989; Kumaratilake et al., 1989). Both are associated with the beads of the microfibrils and likely stabilize individual microfibrils through lateral connections between beads thereby organizing the microfibrils into parallel arrangements within bundles (cables) (Cain et al., 2006; Henderson et al., 1996; Trask et al., 2000), possibly contributing to the unidirectionality of the fibrillin molecules (Hubmacher et al., 2008).

Another important protein associated with fibrillin is latent transforming growth factor $\beta$ binding protein 1 (LTBP-1) present in some tissues but not others. Fibrillin and LTBPs are structurally very similar and have a domain module (the 8-cysteine containing domain) found only in these two proteins. LTBP-1 forms a complex with latent TGF- $\beta$ and assists with the secretion and targeting of TGF- $\beta$ to the extracellular matrix. LTBP-1 is bound to fibrillin but is probably not a component of the microfibril itself (Isogai et al., 2003). The interaction between fibrillin and LTBP- 1 results in sequestration of TGF- $\beta$ in the extracellular matrix. It has been suggested that tensile force extends the small latent TGF- $\beta$ complex within the fibrillin/LTBP environment, enabling release and activation of TGF- $\beta$ (Isogai et al., 2003; Shi et al., 2011; Wipff and Hinz, 2008).

The number and variety of proteins associated with fibrillin clearly suggest microfibrils serve multiple functions in addition to functioning as a structural support and scaffold for elastogenesis (Charbonneau et al., 2004; Kielty et al., 2002; Ramirez and Dietz, 2007). This applies equally as well to the cornea. However, despite the rapidly accumulating information about the above macromolecules, the role(s) of each protein in microfibril function remains unclear. 


\section{Functional considerations}

If we were to conclude that adult cornea stroma does not contain EFMBs then we would assume that their presence in maturing stroma serves a developmental function. However, unpublished evidence from our lab supports the notion of a well-developed EFMB network in the normal adult corneal stroma. Coupling information gleaned from studies of EFMBs in non-corneal tissues with our observations of corneal EFMBs allows us to speculate on their function(s).

The continuum of elastic tissue from elastin-free to predominantly elastin implies a similar continuum of mechanical properties appropriate for their location. Elastic tissue void of elastin (i.e. EFMBs) is frequently found associated with structures requiring rigidity in order to withstand mechanical forces and there is evidence that mechanical loading stimulates fiber synthesis (Charbonneau et al., 2004; Ramirez et al., 2004; Strydom et al., 2012).

Mechanical/physical properties of microfibrils may be adapted to the specific tissue requirements and even be temporally modulated depending on the physical demands (e.g., load or sheer forces). The periodontal and nuchal ligaments are examples that have been extensively studied. In the eye, the lens zonules are often mentioned as prime examples where EFMBs are important for their mechanical properties. Corneal biomechanical properties would also be consistent with EFMBs properties. Case in point, corneal stromal EFMBs may attach posteriorly to Descemet's and may serve to anchor the stroma to Descemet's (Garner and Alexander, 1986). The anchoring functions of EFMBs are well documented in other tissues including the periodontal ligament and ciliary zonules (Davis, 1994; Montes, 1996).

In addition to structural support, EFMBs may also have a mechanotransduction role. For example it has been shown that EFMBs are associated with arteries and lymphatic vessels with the suggestion that they may assist in modulating vessel diameter and thereby assist in blood flow regulation and lymphatic clearance of edematous extracellular fluid (Gerli et al., 1991; Leak and Burke, 1968; Strydom et al., 2012). This could imply, following corneal injury, stromal swelling imparts a mechanical force on the EFMBs and this strain is transferred to the lymphatics, pulling them open to facilitate tissue edema clearance. Similarly, after corneal wounding, microfibril attachments to limbal blood venules may aid in vessel dilation and assist with inflammatory cell recruitment. EFMBs mechanotransduction may also involve cell signaling between cells and ECM fibrillin via integrin outside-in signaling influencing cell shape and migration (Bax et al., 2003; Gregory et al., 2005; Isogai et al., 2003; Pfaff et al., 1996; Ramirez and Rifkin, 2003; Strydom et al., 2012). Cell signaling through EFMB binding may also be involved in homeostasis through growth factor and bone morphogenetic protein (BMP) interactions (Ramirez and Dietz, 2007). A key example is when disruption of quantity or functional capacity of microfibrils as a result of fibrillin-1 gene mutation leads to perturbed TGF $\beta$ signaling seen in fibrillinopathies (Loeys et al., 2010; Ramirez and Rifkin, 2009). It is now clear that fibrillin-1 (along with other ECM proteins) interacts with a large number of cell matrix components and cell-surface integrin receptors (Pfaff et al., 1996; Sakamoto et al., 1996).

Exp Eye Res. Author manuscript; available in PMC 2016 March 01. 


\section{Fibrillinopathies}

Observed downstream consequences of genetic mutations resulting in molecules being absent or perturbed provides valuable clues to their function. Marfans Syndrome is a prime example of a genetic mutation that affects multiple organ systems, including the eye, and implicates a common element which, in this case, is fibrillin.

A few years after the discovery of fibrillin, mutations in the gene which encodes fibrillin (FBN1) were shown to be the cause of Marfans syndrome (MFS) (Dietz et al., 1993). MFS is a pleiotropic autosomal dominant systemic disorder of connective tissue with a large variability in clinical presentation manifesting in skeletal, cardiovascular and ocular systems. Ocular effects include retinal detachment, increased axial length and myopia, flattened corneal curvature, iris and ciliary muscle hypoplasia, and lens dislocation (ectopia lentis). Over 1,800 different mutations in fibrillin 1 have been identified (UMD-FBN1 mutation database, updated August 28, 2014; http://www.umd.be/FBN1/) which are attributed to a wide variety of fibrillinopathies (Collod-Beroud et al., 2003; Faivre et al., 2007). The most common are MFS, autosomal dominant Weil-Marchesani syndrome both caused by mutations in fibrillin-1, and Beal's syndrome caused by mutations in fibrillin-2 (Robinson et al., 2006).

FBN1 gene mutation leads to microfibril disorganization and reduced amounts of fibrillin (Aoyama et al., 1994; Aoyama et al., 1995; Aoyama et al., 1993; Hollister et al., 1990; Kielty and Shuttleworth, 1994; Milewicz et al., 1992) which not only cause structural and biomechanical abnormalities but also activation of TGF- $\beta$ and perturbed signaling. This likely explains some of the variable phenotypic features seen in MFS (Bunton et al., 2001; Isogai et al., 2003; Loeys et al., 2010; Neptune et al., 2003; $\mathrm{Ng}$ et al., 2004; Ramirez and Dietz, 2007; Ramirez et al., 1999; Ramirez and Rifkin, 2003, 2009; Ramirez et al., 2004) and has provided rationale for a new drug-based strategy based on TGF-b antagonism (Habashi et al., 2006).

In addition to systemic manifestations of fibrillinopathies there are also a variety of corneal diseases/conditions associated with fibrillin expression. While numerous authors have reported the absence of EFMBs in adult (human) corneas, there are many reports of fibrillin expression with corneal diseases such as bullous keratopathy (Akhtar et al., 2001), Salzmann's dystrophy (Obata et al., 2006), Fuch's dystrophy (Garner and Alexander, 1986), posterior polymorphous dystrophy (Garner and Alexander, 1986), Hassall-Henle warts (Garner and Alexander, 1986) and keratoconus (Garner and Alexander, 1986).

Fibrillin-1 accumulation has been observed in corneal wound healing (Maguen et al., 1997). With corneal ectasia following LASIK surgery, collagen fibers may be replaced by microfibrils and there may be an accumulation of microfibrils between the flap and stromal bed (Akhtar et al., 2013). Sustained severely elevated IOP may cause corneal scarring with associated microfibrils (Garner and Alexander, 1986). It has also been shown that mechanical loading of EFMBs stimulates synthesis of new fibers (Jonas and Riede, 1980).

Exp Eye Res. Author manuscript; available in PMC 2016 March 01. 


\section{Concluding remarks}

Nearly all connective tissue contains elements of elastic tissue. After nearly two centuries of extensive research involving elastic tissue there are still many unanswered questions in regards to the inclusion and role of elastic tissue in the cornea. Fibrillin, the main protein comprising the microfibrils contained within elastic tissue, was not discovered until 1986. Since its discovery, numerous systemic fibrillinopathies have been linked to mutations in the fibrillin gene, including Marfans Syndrome. Only relatively recently has the molecular structure of fibrillin been determined as well as its association with cells and numerous other molecules. This evidence suggests fibrillin microfibrils (EFMBs) have multiple functions beyond the initial concept of providing elastic properties.

In this review we referenced several published reports stating that EFMBs are not a part of the normal, non-diseased adult corneal stroma. However, we also presented new evidence from our laboratory confirming the presence of an extensive network or EFMBs within the adult mouse cornea. Although not as thoroughly described, we also show evidence of EFMBs in adult animals in several other species. Information gleaned from previous studies involving non-cornea tissues has provided substantial information regarding the structure, distribution, and proposed roles of elastic tissue microfibrils, much of which may apply to the cornea as well. The presence of fibrillin microfibrils in the adult corneal stroma implores us to further understand their role in health and disease.

\section{Acknowledgments}

We thank Evelyn Brown for her excellent help in preparation of EM specimens, and Paul Harris, Paul Landry, Siri Magadi, Nancy Shenoi, and Ian Smith for segmentation and 3D image reconstruction. Research results reported from our laboratory were obtained from projects supported by NEI grants: EY17120, EY007551 and HL116524.

\section{References}

Abelsdorff G. Horstmann C. Tartuferi. On the elastic tissue of the cornea and a particular method of metallic impregnation. Systematic Report on the Progress of Ophthalmology in the Third Quarter of the Year 1903. Archives of Ophthalmology. 1904; 33:561.

Akhtar S, Alkatan H, Kirat O, Almubrad T. Ultrastructural and three-dimensional study of postLASIK ectasia cornea. Microscopy research and technique. 2013

Akhtar S, Bron AJ, Hawksworth NR, Bonshek RE, Meek KM. Ultrastructural morphology and expression of proteoglycans, betaig-h3, tenascin-C, fibrillin-1, and fibronectin in bullous keratopathy. The British journal of ophthalmology. 2001; 85:720-731. [PubMed: 11371495]

Alexander RA, Clayton DC, Howes RC, Garner A. Effect of oxidation upon demonstration of corneal oxytalan fibres: a light and electron microscopical study. Medical laboratory sciences. 1981; 38:91101. [PubMed: 7339416]

Alexander RA, Garner A. Elastic and precursor fibres in the normal human eye. Experimental eye research. 1983; 36:305-315. [PubMed: 6825743]

Alroy J, Haskins M, Birk DE. Altered corneal stromal matrix organization is associated with mucopolysaccharidosis I, III and VI. Experimental eye research. 1999; 68:523-530. [PubMed: 10328965]

Aoyama T, Francke U, Dietz HC, Furthmayr H. Quantitative differences in biosynthesis and extracellular deposition of fibrillin in cultured fibroblasts distinguish five groups of Marfan syndrome patients and suggest distinct pathogenetic mechanisms. The Journal of clinical investigation. 1994; 94:130-137. [PubMed: 8040255]

Exp Eye Res. Author manuscript; available in PMC 2016 March 01. 
Aoyama T, Francke U, Gasner C, Furthmayr H. Fibrillin abnormalities and prognosis in Marfan syndrome and related disorders. American journal of medical genetics. 1995; 58:169-176. [PubMed: 8533811]

Aoyama T, Tynan K, Dietz HC, Francke U, Furthmayr H. Missense mutations impair intracellular processing of fibrillin and microfibril assembly in Marfan syndrome. Human molecular genetics. 1993; 2:2135-2140. [PubMed: 8111384]

Baldock C, Koster AJ, Ziese U, Rock MJ, Sherratt MJ, Kadler KE, Shuttleworth CA, Kielty CM. The supramolecular organization of fibrillin-rich microfibrils. The Journal of cell biology. 2001; 152:1045-1056. [PubMed: 11238459]

Banfield WG, Brindley DC. Preliminary Observations on Senile Elastosis Using the Electron Microscope. The Journal of investigative dermatology. 1963; 41:9-17. [PubMed: 14043013]

Bax DV, Bernard SE, Lomas A, Morgan A, Humphries J, Shuttleworth CA, Humphries MJ, Kielty CM. Cell adhesion to fibrillin-1 molecules and microfibrils is mediated by alpha 5 beta 1 and alpha v beta 3 integrins. The Journal of biological chemistry. 2003; 278:34605-34616. [PubMed: 12807887]

Birk DE. Type V collagen: heterotypic type I/V collagen interactions in the regulation of fibril assembly. Micron. 2001; 32:223-237. [PubMed: 11006503]

Brown-Augsburger P, Broekelmann T, Mecham L, Mercer R, Gibson MA, Cleary EG, Abrams WR, Rosenbloom J, Mecham RP. Microfibril-associated glycoprotein binds to the carboxyl-terminal domain of tropoelastin and is a substrate for transglutaminase. The Journal of biological chemistry. 1994; 269:28443-28449. [PubMed: 7961786]

Bruns RR, Press W, Gross J. A large-scale, orthogonal network of microfibril bundles in the corneal stroma. Investigative ophthalmology \& visual science. 1987; 28:1939-1946. [PubMed: 3119511]

Bunton TE, Biery NJ, Myers L, Gayraud B, Ramirez F, Dietz HC. Phenotypic alteration of vascular smooth muscle cells precedes elastolysis in a mouse model of Marfan syndrome. Circulation research. 2001; 88:37-43. [PubMed: 11139471]

Cain SA, Morgan A, Sherratt MJ, Ball SG, Shuttleworth CA, Kielty CM. Proteomic analysis of fibrillin-rich microfibrils. Proteomics. 2006; 6:111-122. [PubMed: 16302274]

Carlson EC, Waring GO 3rd. Ultrastructural analyses of enzyme-treated microfibrils in rabbit corneal stroma. Investigative ophthalmology \& visual science. 1988; 29:578-585. [PubMed: 3281915]

Carrington SD, Alexander RA, Grierson I. Elastic and related fibres in the normal cornea and limbus of the domestic cat. Journal of anatomy. 1984; 139(Pt 2):319-332. [PubMed: 6490521]

Charbonneau NL, Dzamba BJ, Ono RN, Keene DR, Corson GM, Reinhardt DP, Sakai LY. Fibrillins can co-assemble in fibrils, but fibrillin fibril composition displays cell-specific differences. The Journal of biological chemistry. 2003; 278:2740-2749. [PubMed: 12429739]

Charbonneau NL, Jordan CD, Keene DR, Lee-Arteaga S, Dietz HC, Rifkin DB, Ramirez F, Sakai LY. Microfibril structure masks fibrillin-2 in postnatal tissues. The Journal of biological chemistry. 2010; 285:20242-20251. [PubMed: 20404337]

Charbonneau NL, Ono RN, Corson GM, Keene DR, Sakai LY. Fine tuning of growth factor signals depends on fibrillin microfibril networks. Birth defects research. Part C, Embryo today : reviews. 2004; 72:37-50.

Coleman DJ, Trokel S. Direct-recorded intraocular pressure variations in a human subject. Archives of ophthalmology. 1969; 82:637-640. [PubMed: 5357713]

Collod-Beroud G, Le Bourdelles S, Ades L, Ala-Kokko L, Booms P, Boxer M, Child A, Comeglio P, De Paepe A, Hyland JC, Holman K, Kaitila I, Loeys B, Matyas G, Nuytinck L, Peltonen L, Rantamaki T, Robinson P, Steinmann B, Junien C, Beroud C, Boileau C. Update of the UMDFBN1 mutation database and creation of an FBN1 polymorphism database. Human mutation. 2003; 22:199-208. [PubMed: 12938084]

Corson GM, Chalberg SC, Dietz HC, Charbonneau NL, Sakai LY. Fibrillin binds calcium and is coded by cDNAs that reveal a multidomain structure and alternatively spliced exons at the $5^{\prime}$ end. Genomics. 1993; 17:476-484. [PubMed: 7691719]

Corson GM, Charbonneau NL, Keene DR, Sakai LY. Differential expression of fibrillin-3 adds to microfibril variety in human and avian, but not rodent, connective tissues. Genomics. 2004; 83:461-472. [PubMed: 14962672]

Exp Eye Res. Author manuscript; available in PMC 2016 March 01. 
Cotta-Pereira G, Guerra Rodrigo F, Bittencourt-Sampaio S. Oxytalan, elaunin, and elastic fibers in the human skin. The Journal of investigative dermatology. 1976; 66:143-148. [PubMed: 1249442]

Daga Gordini D, Castellani I, Volpin D, Bressan GM. Ultrastructural immuno-localization of tropoelastin in the chick eye. Cell and tissue research. 1990; 260:137-146. [PubMed: 2340579]

Davis EC. Stability of elastin in the developing mouse aorta: a quantitative radioautographic study. Histochemistry. 1993; 100:17-26. [PubMed: 8226106]

Davis EC. Immunolocalization of microfibril and microfibril-associated proteins in the subendothelial matrix of the developing mouse aorta. Journal of cell science. 1994; 107(Pt 3):727-736. [PubMed: 8006086]

Denk W, Horstmann H. Serial block-face scanning electron microscopy to reconstruct threedimensional tissue nanostructure. PLoS biology. 2004; 2:e329. [PubMed: 15514700]

Dietz HC, McIntosh I, Sakai LY, Corson GM, Chalberg SC, Pyeritz RE, Francomano CA. Four novel FBN1 mutations: significance for mutant transcript level and EGF-like domain calcium binding in the pathogenesis of Marfan syndrome. Genomics. 1993; 17:468-475. [PubMed: 8406497]

Eriksen TA, Wright DM, Purslow PP, Duance VC. Role of $\mathrm{Ca}(2+)$ for the mechanical properties of fibrillin. Proteins. 2001; 45:90-95. [PubMed: 11536364]

Faivre L, Collod-Beroud G, Loeys BL, Child A, Binquet C, Gautier E, Callewaert B, Arbustini E, Mayer K, Arslan-Kirchner M, Kiotsekoglou A, Comeglio P, Marziliano N, Dietz HC, Halliday D, Beroud C, Bonithon-Kopp C, Claustres M, Muti C, Plauchu H, Robinson PN, Ades LC, Biggin A, Benetts B, Brett M, Holman KJ, De Backer J, Coucke P, Francke U, De Paepe A, Jondeau G, Boileau C. Effect of mutation type and location on clinical outcome in 1,013 probands with Marfan syndrome or related phenotypes and FBN1 mutations: an international study. American journal of human genetics. 2007; 81:454-466. [PubMed: 17701892]

Faury G. Function-structure relationship of elastic arteries in evolution: from microfibrils to elastin and elastic fibres. Pathologie-biologie. 2001; 49:310-325. [PubMed: 11428167]

Fitch JM, Birk DE, Linsenmayer C, Linsenmayer TF. Stromal assemblies containing collagen types IV and VI and fibronectin in the developing embryonic avian cornea. Developmental biology. 1991; 144:379-391. [PubMed: 2010037]

Fullmer HM, Lillie RD. The oxytalan fiber: a previously undescribed connective tissue fiber. The journal of histochemistry and cytochemistry : official journal of the Histochemistry Society. 1958; 6:425-430. [PubMed: 13598878]

Garner A, Alexander RA. Histochemistry of elastic and related fibres in the human eye in health and disease. The Histochemical journal. 1986; 18:405-412. [PubMed: 3781873]

Gawlik Z. Morphological and morphochemical properties of the elastic system in the motor organ of man. Folia histochemica et cytochemica. 1965; 3:233-251. [PubMed: 4160090]

Gerli R, Ibba L, Fruschelli C. Ultrastructural cytochemistry of anchoring filaments of human lymphatic capillaries and their relation to elastic fibers. Lymphology. 1991; 24:105-112. [PubMed: 1753801]

Gibson MA, Cleary EG. The immunohistochemical localisation of microfibril-associated glycoprotein (MAGP) in elastic and non-elastic tissues. Immunology and cell biology. 1987; 65(Pt 4):345-356. [PubMed: 3315986]

Gibson MA, Kumaratilake JS, Cleary EG. The protein components of the 12-nanometer microfibrils of elastic and nonelastic tissues. The Journal of biological chemistry. 1989; 264:4590-4598. [PubMed: 2647740]

Goldman JN, Benedek GB, Dohlman CH, Kravitt B. Structural alterations affecting transparency in swollen human corneas. Investigative ophthalmology. 1968; 7:501-519. [PubMed: 5693186]

Greenlee TK Jr, Ross R, Hartman JL. The fine structure of elastic fibers. The Journal of cell biology. 1966; 30:59-71. [PubMed: 4165078]

Gregory KE, Ono RN, Charbonneau NL, Kuo CL, Keene DR, Bachinger HP, Sakai LY. The prodomain of BMP-7 targets the BMP-7 complex to the extracellular matrix. The Journal of biological chemistry. 2005; 280:27970-27980. [PubMed: 15929982]

Habashi JP, Judge DP, Holm TM, Cohn RD, Loeys BL, Cooper TK, Myers L, Klein EC, Liu G, Calvi C, Podowski M, Neptune ER, Halushka MK, Bedja D, Gabrielson K, Rifkin DB, Carta L, Ramirez 
F, Huso DL, Dietz HC. Losartan, an AT1 antagonist, prevents aortic aneurysm in a mouse model of Marfan syndrome. Science. 2006; 312:117-121. [PubMed: 16601194]

Hann CR, Fautsch MP. The elastin fiber system between and adjacent to collector channels in the human juxtacanalicular tissue. Investigative ophthalmology \& visual science. 2011; 52:45-50. [PubMed: 20720231]

Hassell JR, Birk DE. The molecular basis of corneal transparency. Experimental eye research. 2010; 91:326-335. [PubMed: 20599432]

Haust MD. Fine fibrils of extracellular space (microfibrils). Their structure and role in connective tissue organization. The American journal of pathology. 1965; 47:1113-1137. [PubMed: 5844381]

Haust MD, More RH, Bencosme SA, Balis JU. Elastogenesis in human aorta: an electron microscopic study. Experimental and molecular pathology. 1965; 4:508-524. [PubMed: 5847769]

Hayes S, Boote C, Lewis J, Sheppard J, Abahussin M, Quantock AJ, Purslow C, Votruba M, Meek KM. Comparative study of fibrillar collagen arrangement in the corneas of primates and other mammals. Anatomical record. 2007; 290:1542-1550.

Henderson M, Polewski R, Fanning JC, Gibson MA. Microfibril-associated glycoprotein-1 (MAGP-1) is specifically located on the beads of the beaded-filament structure for fibrillin-containing microfibrils as visualized by the rotary shadowing technique. The journal of histochemistry and cytochemistry : official journal of the Histochemistry Society. 1996; 44:1389-1397. [PubMed: 8985131]

Hogan, MJ.; Alvarado, JA.; Weddell, JP. Histology of the human eye. W.B. Saunders; Philadelphia: 1971.

Hollister DW, Godfrey M, Sakai LY, Pyeritz RE. Immunohistologic abnormalities of the microfibrillar-fiber system in the Marfan syndrome. The New England journal of medicine. 1990; 323:152-159. [PubMed: 2194127]

Hubmacher D, El-Hallous EI, Nelea V, Kaartinen MT, Lee ER, Reinhardt DP. Biogenesis of extracellular microfibrils: Multimerization of the fibrillin-1 C terminus into bead-like structures enables self-assembly. Proceedings of the National Academy of Sciencesof the United States of America. 2008; 105:6548-6553.

Isogai Z, Ono RN, Ushiro S, Keene DR, Chen Y, Mazzieri R, Charbonneau NL, Reinhardt DP, Rifkin DB, Sakai LY. Latent transforming growth factor beta-binding protein 1 interacts with fibrillin and is a microfibril-associated protein. The Journal of biological chemistry. 2003; 278:2750-2757. [PubMed: 12429738]

Jensen SA, Robertson IB, Handford PA. Dissecting the fibrillin microfibril: structural insights into organization and function. Structure. 2012; 20:215-225. [PubMed: 22325771]

Jonas IE, Riede UN. Reaction of oxytalan fibers in human periodontium to mechanical stress. A combined histochemical and morphometric analysis. The journal of histochemistry and cytochemistry : official journal of the Histochemistry Society. 1980; 28:211-216. [PubMed: 7354216]

Jovanovic J, Iqbal S, Jensen S, Mardon H, Handford P. Fibrillin-integrin interactions in health and disease. Biochemical Society transactions. 2008; 36:257-262. [PubMed: 18363569]

Kanai A, Kaufman HE. Electron microscopic studies of the elastic fiber in human sclera. Investigative ophthalmology. 1972; 11:816-821. [PubMed: 4561130]

Keene DR, Maddox BK, Kuo HJ, Sakai LY, Glanville RW. Extraction of extendable beaded structures and their identification as fibrillin-containing extracellular matrix microfibrils. The journal of histochemistry and cytochemistry : official journal of the Histochemistry Society. 1991; 39:441449. [PubMed: 2005373]

Kielty CM, Baldock C, Lee D, Rock MJ, Ashworth JL, Shuttleworth CA. Fibrillin: from microfibril assembly to biomechanical function. Philosophical transactions of the Royal Society of London. Series B, Biological sciences. 2002; 357:207-217.

Kielty CM, Shuttleworth CA. Abnormal fibrillin assembly by dermal fibroblasts from two patients with Marfan syndrome. The Journal of cell biology. 1994; 124:997-1004. [PubMed: 8132720]

Kielty CM, Shuttleworth CA. Fibrillin-containing microfibrils: structure and function in health and disease. The international journal of biochemistry \& cell biology. 1995; 27:747-760. [PubMed: 7584608]

Exp Eye Res. Author manuscript; available in PMC 2016 March 01. 
Kolliker, A. Manual of Human Microscopic Anatomy. J.W. Parker; London: 1860.

Kuchtey J, Kuchtey RW. The microfibril hypothesis of glaucoma: implications for treatment of elevated intraocular pressure. Journal of ocular pharmacology and therapeutics : the official journal of the Association for Ocular Pharmacology and Therapeutics. 2014; 30:170-180.

Kuhn C, Yu SY, Chraplyvy M, Linder HE, Senior RM. The induction of emphysema with elastase. II. Changes in connective tissue. Laboratory investigation; a journal of technical methods and pathology. 1976; 34:372-380.

Kumaratilake JS, Gibson MA, Fanning JC, Cleary EG. The tissue distribution of microfibrils reacting with a monospecific antibody to MAGP, the major glycoprotein antigen of elastin-associated microfibrils. European journal of cell biology. 1989; 50:117-127. [PubMed: 2693088]

Kuo CL, Isogai Z, Keene DR, Hazeki N, Ono RN, Sengle G, Bachinger HP, Sakai LY. Effects of fibrillin-1 degradation on microfibril ultrastructure. The Journal of biological chemistry. 2007; 282:4007-4020. [PubMed: 17158461]

Leak LV, Burke JF. Ultrastructural studies on the lymphatic anchoring filaments. The Journal of cell biology. 1968; 36:129-149.

Lee B, Godfrey M, Vitale E, Hori H, Mattei MG, Sarfarazi M, Tsipouras P, Ramirez F, Hollister DW. Linkage of Marfan syndrome and a phenotypically related disorder to two different fibrillin genes. Nature. 1991; 352:330-334. [PubMed: 1852206]

Lehmann, KG. Physiological Chemistry. 2nd. Blanchard \& Lea; Philadelphia: 1855.

Loeys BL, Gerber EE, Riegert-Johnson D, Iqbal S, Whiteman P, McConnell V, Chillakuri CR, Macaya D, Coucke PJ, De Paepe A, Judge DP, Wigley F, Davis EC, Mardon HJ, Handford P, Keene DR, Sakai LY, Dietz HC. Mutations in fibrillin-1 cause congenital scleroderma: stiff skin syndrome. Science translational medicine. 2010; 2:23ra20.

Low FN. Microfibrils: fine filamentous components of the tissue space. The Anatomical record. 1962; 142:131-137. [PubMed: 14466918]

Lu Y, Holmes DF, Baldock C. Evidence for the intramolecular pleating model of fibrillin microfibril organisation from single particle image analysis. Journal of molecular biology. 2005; 349:73-85. [PubMed: 15876369]

Maguen E, Alba SA, Burgeson RE, Butkowski RJ, Michael AF, Kenney MC, Nesburn AB, Ljubimov AV. Alterations of corneal extracellular matrix after multiple refractive procedures: a clinical and immunohistochemical study. Cornea. 1997; 16:675-682. [PubMed: 9395878]

Maslen CL, Corson GM, Maddox BK, Glanville RW, Sakai LY. Partial sequence of a candidate gene for the Marfan syndrome. Nature. 1991; 352:334-337. [PubMed: 1852207]

Maurice DM. The structure and transparency of the cornea. The Journal of physiology. 1957; 136:263-286. [PubMed: 13429485]

McConnell CJ, DeMont ME, Wright GM. Microfibrils provide non-linear elastic behaviour in the abdominal artery of the lobster Homarus americanus. The Journal of physiology. 1997; 499(Pt 2): 513-526. [PubMed: 9080378]

Milewicz DM, Pyeritz RE, Crawford ES, Byers PH. Marfan syndrome: defective synthesis, secretion, and extracellular matrix formation of fibrillin by cultured dermal fibroblasts. The Journal of clinical investigation. 1992; 89:79-86. [PubMed: 1729284]

Montes GS. Structural biology of the fibres of the collagenous and elastic systems. Cell biology international. 1996; 20:15-27. [PubMed: 8936403]

Neptune ER, Frischmeyer PA, Arking DE, Myers L, Bunton TE, Gayraud B, Ramirez F, Sakai LY, Dietz HC. Dysregulation of TGF-beta activation contributes to pathogenesis in Marfan syndrome. Nature genetics. 2003; 33:407-411. [PubMed: 12598898]

Ng CM, Cheng A, Myers LA, Martinez-Murillo F, Jie C, Bedja D, Gabrielson KL, Hausladen JM, Mecham RP, Judge DP, Dietz HC. TGF-beta-dependent pathogenesis of mitral valve prolapse in a mouse model of Marfan syndrome. The Journal of clinical investigation. 2004; 114:1586-1592. [PubMed: 15546004]

Obata H, Inoki T, Tsuru T. Identification of oxytalan fibers in Salzmann's nodular degeneration. Cornea. 2006; 25:586-589. [PubMed: 16783148]

Exp Eye Res. Author manuscript; available in PMC 2016 March 01. 
Parfitt GJ, Pinali C, Young RD, Quantock AJ, Knupp C. Three-dimensional reconstruction of collagen-proteoglycan interactions in the mouse corneal stroma by electron tomography. Journal of structural biology. 2010; 170:392-397. [PubMed: 20132890]

Pereira L, D'Alessio M, Ramirez F, Lynch JR, Sykes B, Pangilinan T, Bonadio J. Genomic organization of the sequence coding for fibrillin, the defective gene product in Marfan syndrome. Human molecular genetics. 1993; 2:961-968. [PubMed: 8364578]

Pfaff M, Reinhardt DP, Sakai LY, Timpl R. Cell adhesion and integrin binding to recombinant human fibrillin-1. FEBS letters. 1996; 384:247-250. [PubMed: 8617364]

Quondamatteo F, Reinhardt DP, Charbonneau NL, Pophal G, Sakai LY, Herken R. Fibrillin-1 and fibrillin-2 in human embryonic and early fetal development. Matrix biology : journal of the International Society for Matrix Biology. 2002; 21:637-646. [PubMed: 12524050]

Ramirez F, Dietz HC. Fibrillin-rich microfibrils: Structural determinants of morphogenetic and homeostatic events. Journal of cellular physiology. 2007; 213:326-330. [PubMed: 17708531]

Ramirez F, Gayraud B, Pereira L. Marfan syndrome: new clues to genotype-phenotype correlations. Annals of medicine. 1999; 31:202-207. [PubMed: 10442675]

Ramirez F, Rifkin DB. Cell signaling events: a view from the matrix. Matrix biology : journal of the International Society for Matrix Biology. 2003; 22:101-107. [PubMed: 12782137]

Ramirez F, Rifkin DB. Extracellular microfibrils: contextual platforms for TGFbeta and BMP signaling. Current opinion in cell biology. 2009; 21:616-622. [PubMed: 19525102]

Ramirez F, Sakai LY, Dietz HC, Rifkin DB. Fibrillin microfibrils: multipurpose extracellular networks in organismal physiology. Physiological genomics. 2004; 19:151-154. [PubMed: 15466717]

Reinhardt DP, Keene DR, Corson GM, Poschl E, Bachinger HP, Gambee JE, Sakai LY. Fibrillin-1: organization in microfibrils and structural properties. Journal of molecular biology. 1996; 258:104-116. [PubMed: 8613981]

Robinson PN, Arteaga-Solis E, Baldock C, Collod-Beroud G, Booms P, De Paepe A, Dietz HC, Guo G, Handford PA, Judge DP, Kielty CM, Loeys B, Milewicz DM, Ney A, Ramirez F, Reinhardt DP, Tiedemann K, Whiteman P, Godfrey M. The molecular genetics of Marfan syndrome and related disorders. Journal of medical genetics. 2006; 43:769-787. [PubMed: 16571647]

Rosenbloom J, Abrams WR, Mecham R. Extracellular matrix 4: the elastic fiber. FASEB journal : official publication of the Federation of American Societies for Experimental Biology. 1993; 7:1208-1218. [PubMed: 8405806]

Ross R, Bornstein P. The elastic fiber. I. The separation and partial characterization of its macromolecular components. The Journal of cell biology. 1969; 40:366-381. [PubMed: 5812469]

Sakai LY, Keene DR, Engvall E. Fibrillin, a new 350-kD glycoprotein, is a component of extracellular microfibrils. The Journal of cell biology. 1986; 103:2499-2509. [PubMed: 3536967]

Sakamoto H, Broekelmann T, Cheresh DA, Ramirez F, Rosenbloom J, Mecham RP. Cell-type specific recognition of RGD- and non-RGD-containing cell binding domains in fibrillin-1. The Journal of biological chemistry. 1996; 271:4916-4922. [PubMed: 8617764]

Schlotzer-Schrehardt U, von der Mark K, Sakai LY, Naumann GO. Increased extracellular deposition of fibrillin-containing fibrils in pseudoexfoliation syndrome. Investigative ophthalmology \& visual science. 1997; 38:970-984. [PubMed: 9112993]

Sherratt MJ. Tissue elasticity and the ageing elastic fibre. Age. 2009; 31:305-325. [PubMed: 19588272]

Sherratt MJ, Baldock C, Haston JL, Holmes DF, Jones CJ, Shuttleworth CA, Wess TJ, Kielty CM. Fibrillin microfibrils are stiff reinforcing fibres in compliant tissues. Journal of molecular biology. 2003; 332:183-193. [PubMed: 12946356]

Shi M, Zhu J, Wang R, Chen X, Mi L, Walz T, Springer TA. Latent TGF-beta structure and activation. Nature. 2011; 474:343-349. [PubMed: 21677751]

Streeten BW, Licari PA, Marucci AA, Dougherty RM. Immunohistochemical comparison of ocular zonules and the microfibrils of elastic tissue. Investigative ophthalmology \& visual science. 1981; 21:130-135. [PubMed: 7019149]

Strydom H, Maltha JC, Kuijpers-Jagtman AM, Von den Hoff JW. The oxytalan fibre network in the periodontium and its possible mechanical function. Archives of oral biology. 2012; 57:10031011. [PubMed: 22784380]

Exp Eye Res. Author manuscript; available in PMC 2016 March 01. 
Tartuferi F. On the elastic tissue of the cornea and a particular method of metallic impregnation. Graefe's Archive of Ophthalmology. 1903; 56:419-438.

Trask BC, Trask TM, Broekelmann T, Mecham RP. The microfibrillar proteins MAGP-1 and fibrillin-1 form a ternary complex with the chondroitin sulfate proteoglycan decorin. Molecular biology of the cell. 2000; 11:1499-1507. [PubMed: 10793130]

Virchow, RLK. Cellular pathology as based upon physiological and pathological histology. 2nd. J.B. Lippincott; Philadelphia: 1863.

Wheatley HM, Traboulsi EI, Flowers BE, Maumenee IH, Azar D, Pyeritz RE, Whittum-Hudson JA. Immunohistochemical localization of fibrillin in human ocular tissues. Relevance to the Marfan syndrome. Archives of ophthalmology. 1995; 113:103-109. [PubMed: 7826283]

Wipff PJ, Hinz B. Integrins and the activation of latent transforming growth factor beta 1 - an intimate relationship. European journal of cell biology. 2008; 87:601-615. [PubMed: 18342983]

Yamamoto S, Hashizume H, Hitomi J, Shigeno M, Sawaguchi S, Abe H, Ushiki T. The subfibrillar arrangement of corneal and scleral collagen fibrils as revealed by scanning electron and atomic force microscopy. Archives of histology and cytology. 2000; 63:127-135. [PubMed: 10885449]

Yanagisawa H, Davis EC. Unraveling the mechanism of elastic fiber assembly: The roles of short fibulins. The international journal of biochemistry \& cell biology. 2010; 42:1084-1093. [PubMed: 20236620]

Zenkel M, Schlotzer-Schrehardt U. Expression and regulation of LOXL1 and elastin-related genes in eyes with exfoliation syndrome. Journal of glaucoma. 2014; 23:S48-50. [PubMed: 25275906]

Zhang H, Apfelroth SD, Hu W, Davis EC, Sanguineti C, Bonadio J, Mecham RP, Ramirez F. Structure and expression of fibrillin-2, a novel microfibrillar component preferentially located in elastic matrices. The Journal of cell biology. 1994; 124:855-863. [PubMed: 8120105]

Exp Eye Res. Author manuscript; available in PMC 2016 March 01. 


\section{Highlights}

- Elasticity is characteristic of fibers containing fibrillin microfibrils and elastin.

- Elastin-free microfibril bundles (EFMBs) are associated with structural support.

- Historically it has been reported EFMBs are non-existent in adult corneal stroma.

- 3D SEM and immunogold labeling verified the presence of EFMBs in adult corneas.

- TEM images provided evidence of EFMBs in the stroma of several mammal species. 


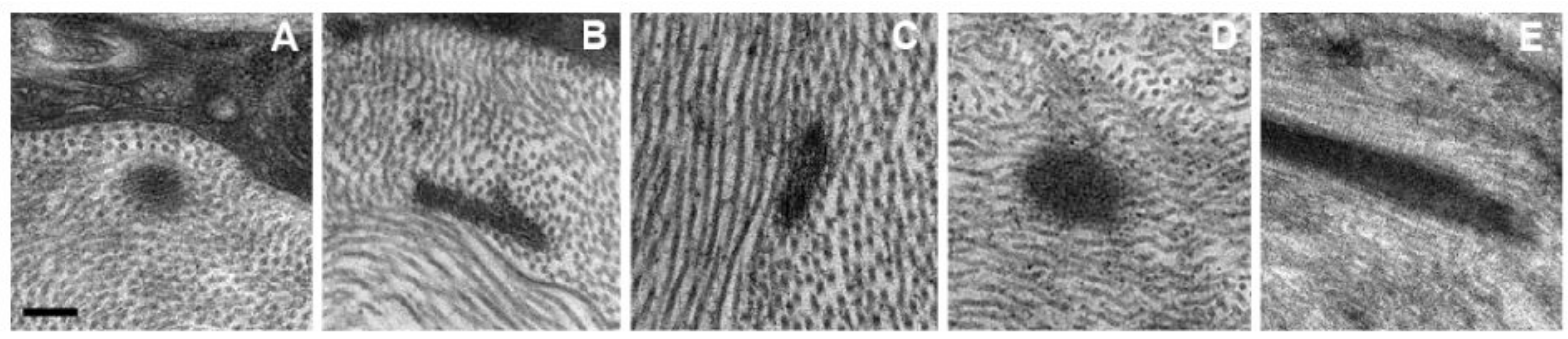

Figure 1.

EM micrographs of 5 mammal species; (a) C57BL/6 mouse, (b) Brown Norway rat, (c) New Zealand White rabbit, (d) Macque monkey, (E) Human. EFMBs are within lamellae in these examples, but they were also located between lamellae. Panels (B) and (C) show EFMBs sectioned obliquely. All images are the same magnification. (Scale bar $=200 \mathrm{~nm})$ 


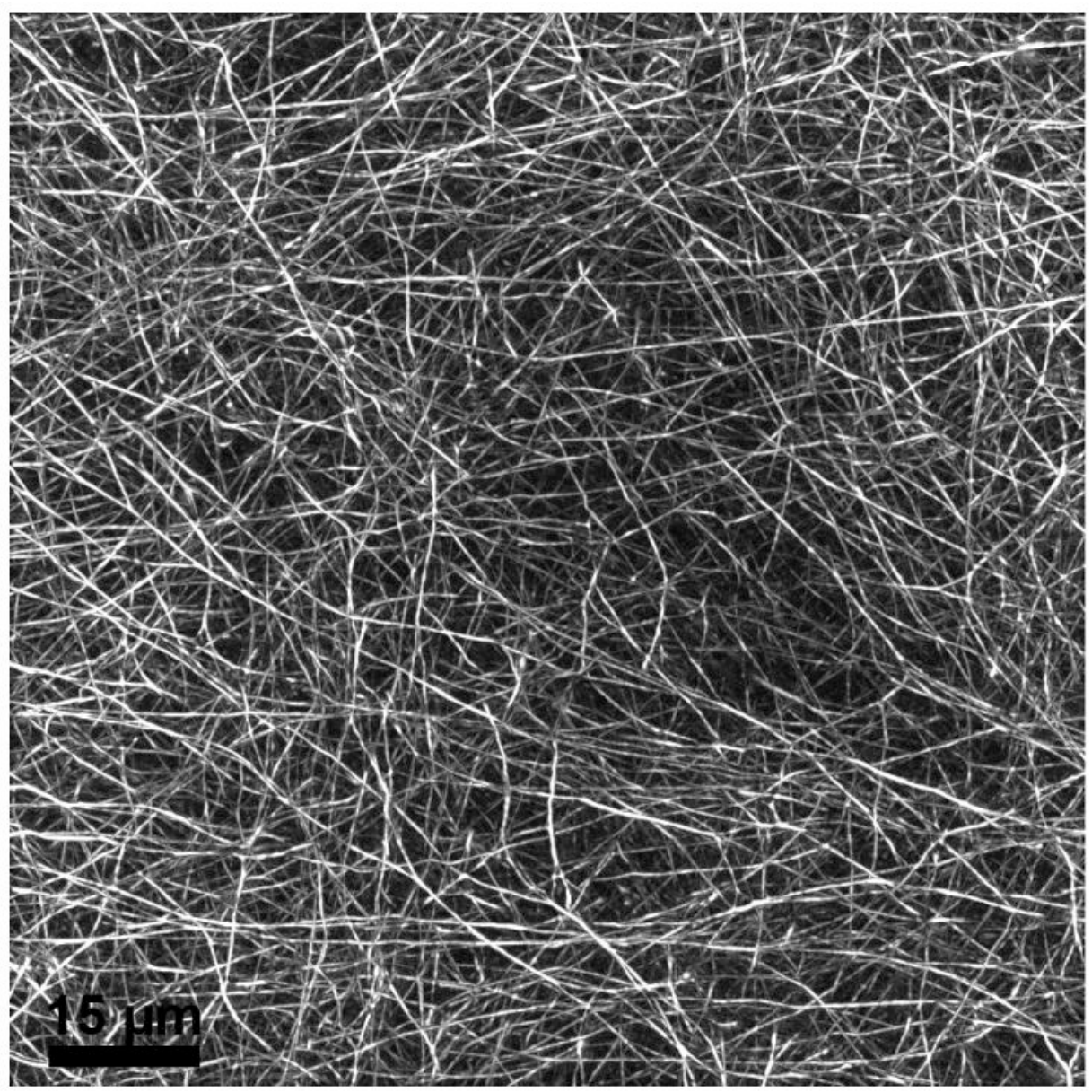

Figure 2.

Maximum intensity projected en face image from fluorescent microscopy of a central $108 \times 108 \mu \mathrm{m}$ area of a mouse cornea whole-mount labeled using anti-fibrillin antibody. 

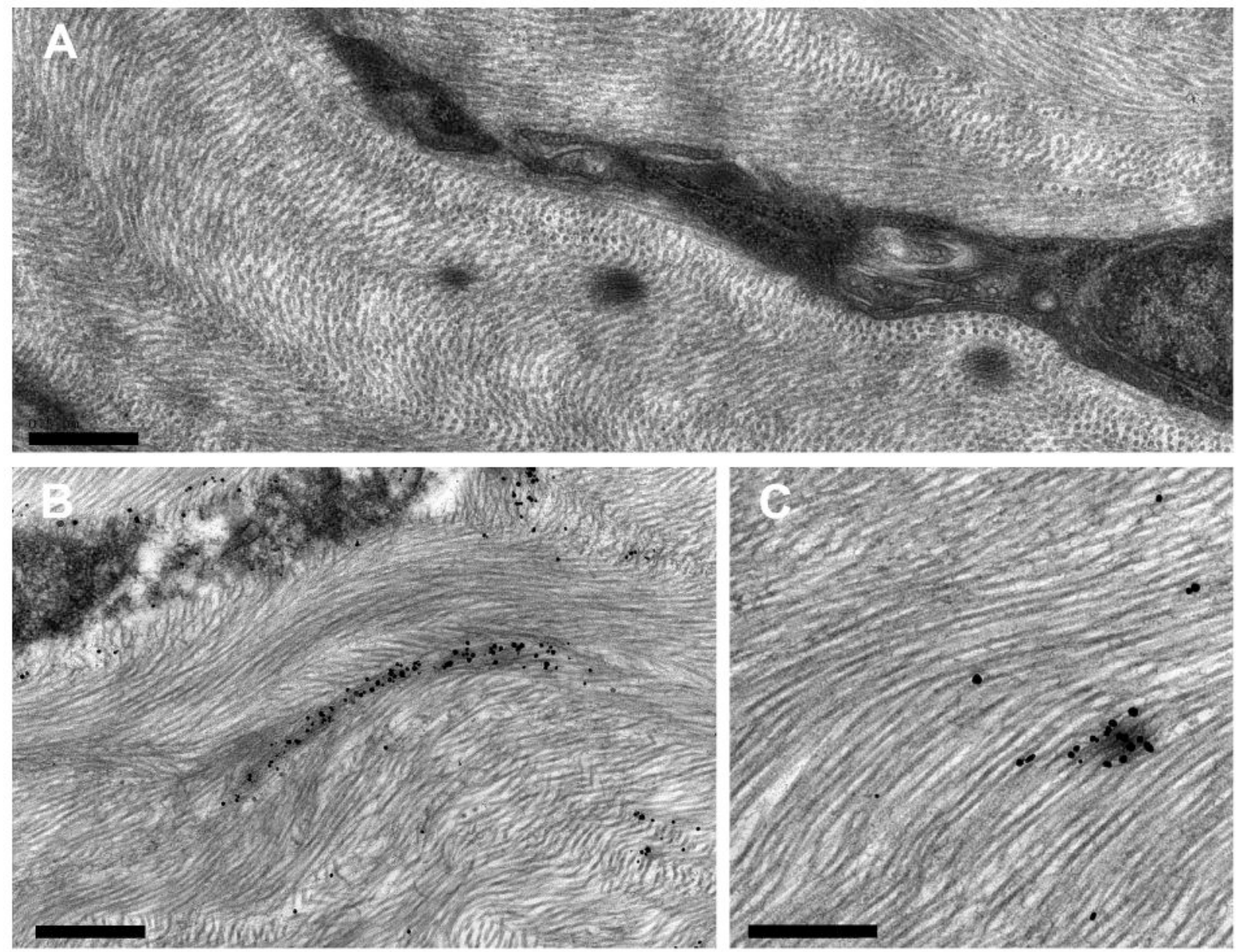

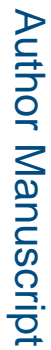

Figure 3.

Electron micrographs of EFMBs in WT mouse. (A) Shows a keratocyte with 3 EFMBs nearby. Panels (B \& C) show fibrillin microfibrils labeled with immuno-gold particles and enhanced with silver. (Scale bars; (A) $500 \mathrm{~nm}$, (B) $750 \mathrm{~nm}$, (C) 500nm) 

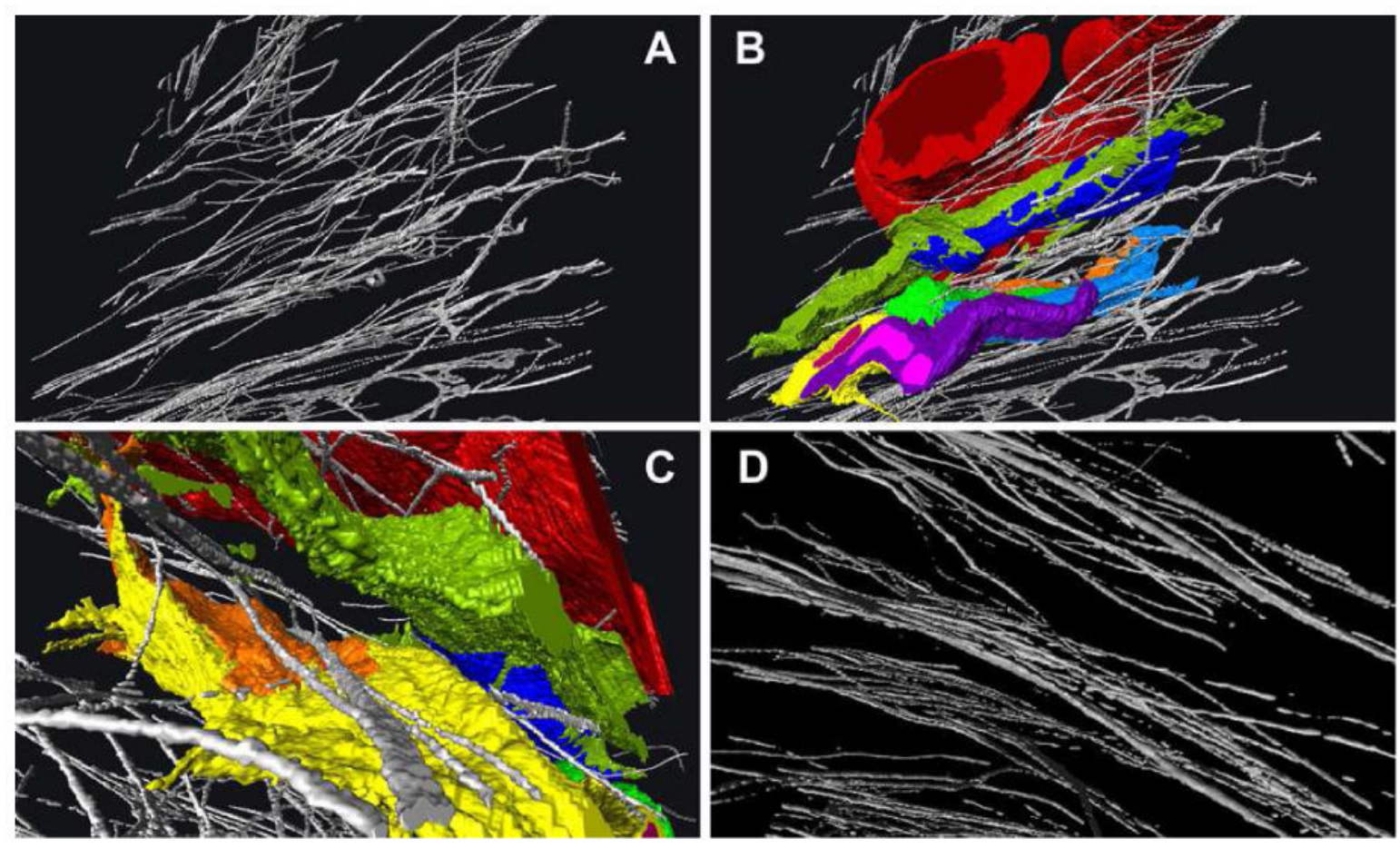

Figure 4.

3D reconstructions from serial SEM block-face images. Panel A shows EFMBs in the limbus, and panel B the same area with blood vessel (red), keratocytes (green, blue, yellow) and neutrophil (purple) in a mouse cornea 6 hours after epithelial wounding. Panel $\mathrm{C}$ is from the same 3D reconstruction as $\mathrm{A}$ and $\mathrm{B}$ but from a different angle and zoomed in to show more detail. From this perspective some EFMBs appear to lie within a groove in the surface of a keratocyte. Panel D is a reconstructed image showing EFMBs in the paracentral cornea with more defined layering as compared to the limbus. Panels A-C are views from an oblique angular perspective while the line of projection in panel $\mathrm{D}$ is nearly parallel with the corneal surface. The average EFMBs were 100-200nm in diameter when measured in crosssection block face images. 

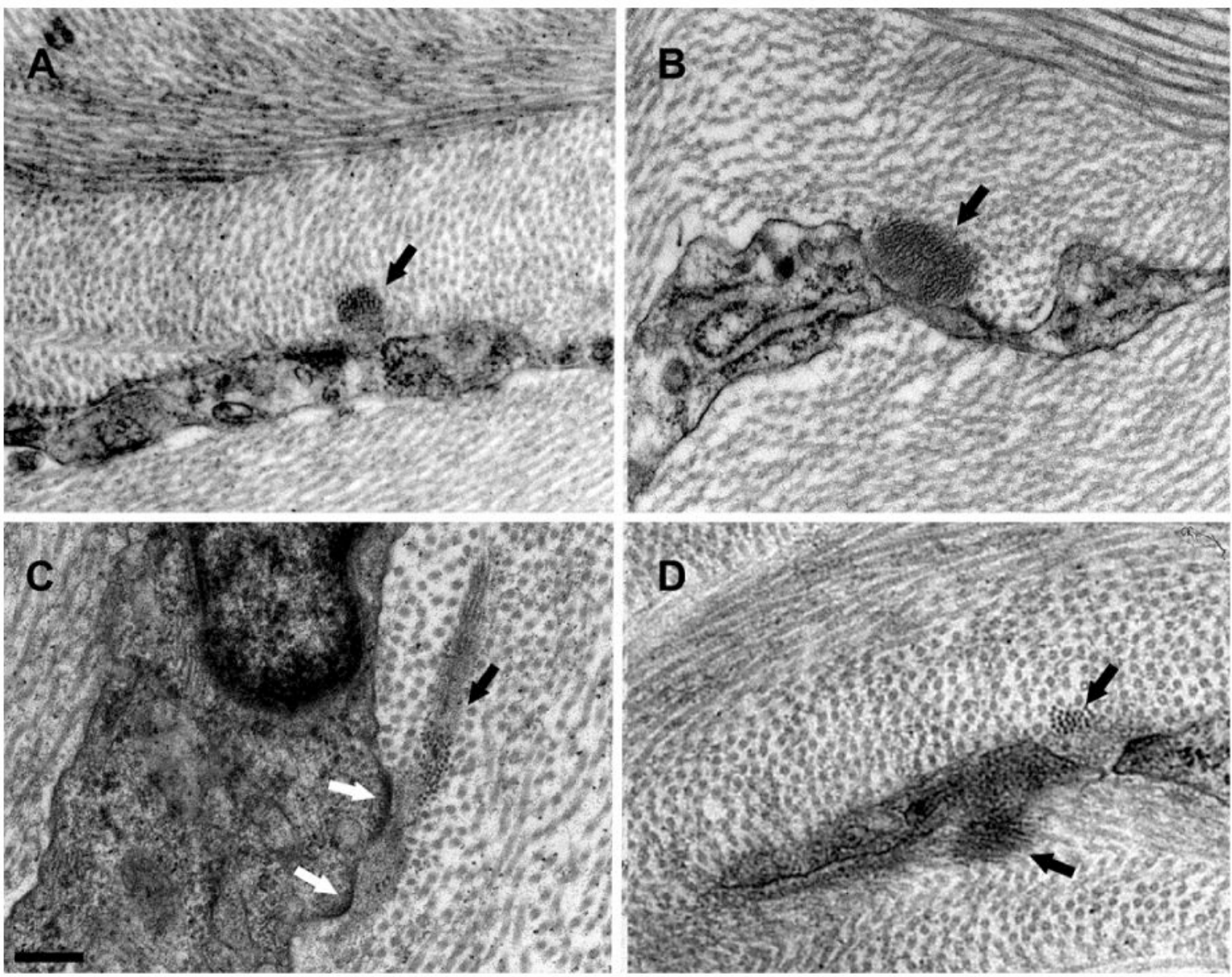

Figure 5.

TEM images showing EFMBs associated with keratocytes. Panels A-D show bundles of microfibrils (black arrows) in proximity to, or making contact with keratocytes. The white arrows in panel $\mathrm{C}$ point to electron dense focal adhesions frequently seen at keratocyteEFMB contacts. $($ Scale bar $=200 \mathrm{~nm})$ 

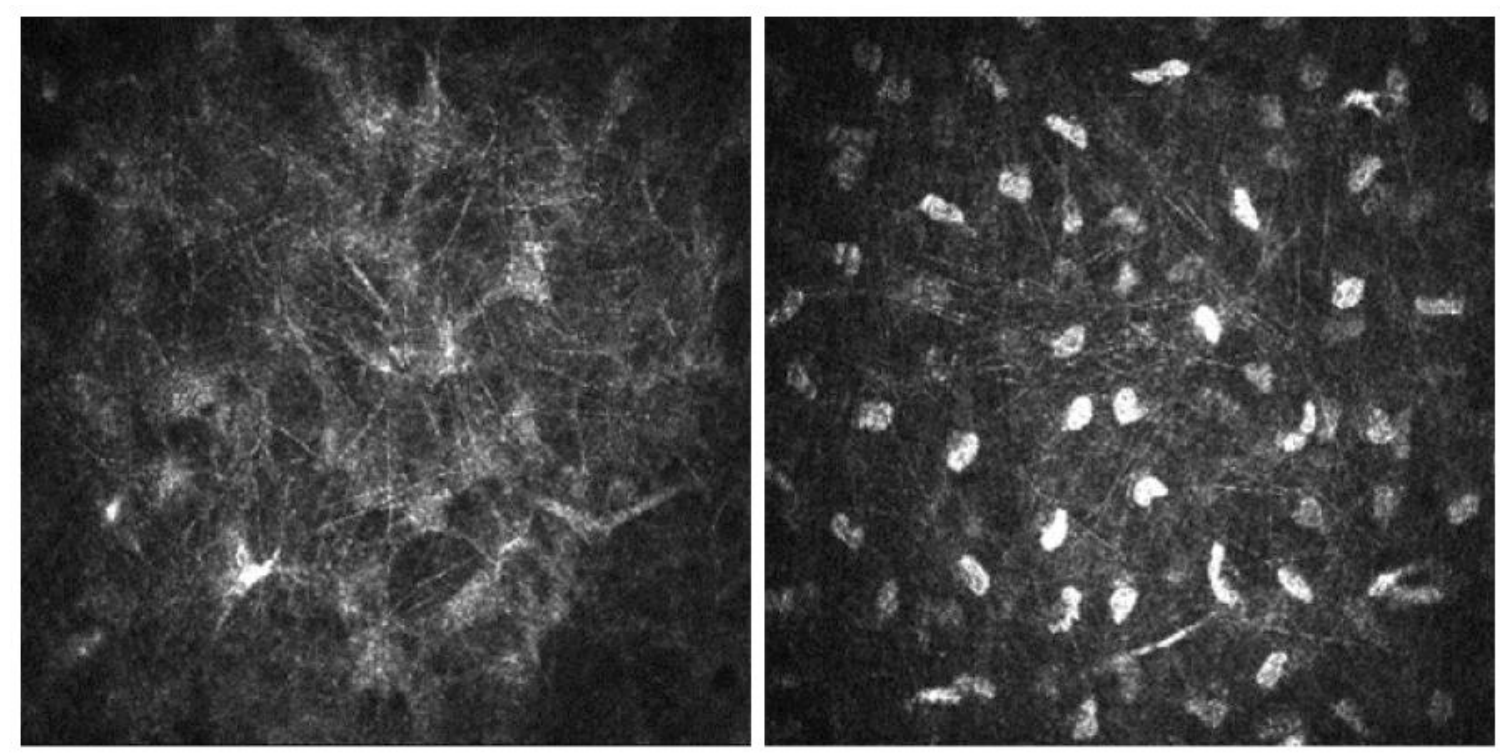

Figure 6.

Images from in vivo confocal microscopy. Left panel shows a fine network of hyperreflective fibers in a mouse cornea. Right panel showing a similar network in a rabbit cornea (large hyper-reflective bodies are keratocyte nuclei, which are not visible in the mouse). 